症例

\author{
男性に発症した閉鎖孔ヘルニアの 2 例 \\ 愛知県厚生連海南病院外科 \\ 榊原巧原田明生矢口豊久
}

閉鎖孔へルニアは男性では非常に稀な疾患である.今回われわれは男性の閉鎖孔へル ニアを 2 例経験した. 症例 1，79歳男性，腹痛，嘔吐を主訴に来院．原因不明の腸閉塞 にてイレウス管留固された。イレウス症状改善せず，4 日後の腹部 CTにて閉鎖孔へル ニアによる腸閉塞と診断し手術施行した。症例 2 , 82歳男性. 数日前からの大腿部痛, 嘔吐を主訴に来院. 即日, 腹部 CTにて閉鎖孔へルニアによる腸閉塞と診断し，緊急手 術施行した，自験例を含め男性報告例では自然解除例はなく，骨盤 CTによる早期の診 断, 手術が特に重要である.男性発症例の特徴についての検討を加えて報告する.

索引用語：閉鎖孔ハルニア，腸閉塞

\section{緒言}

閉鎖孔へルニアは，以前は比較的稀な疾患であった が、現在は日常臨床で常に念頭においておくべ疾患 になりつつある。女性例が95\%を占め男性例は稀であ ろ.今回われわれは男性閉鎖孔ヘルニアの 2 例を経験 したので，これまでの男性閉鎖孔へルニアを集計しそ の特徴を検討して報告する。

$$
\text { 症例 }
$$

症例 $1 ： 79$ 歳, 男性.

主訴：腹痛, 嘔吐.

家族歴：特記すべきことなし。

既往歴：35歳 肺結核, 56歳 脳梗塞.

現病歴：1999年 8 月17日, 腹痛, 嘔吐出現。 8 月18 日当院内科受診し，原因不明のイレウスと診断されイ レウス管留置となった。る月21日イレウス改善傾向な いため，外科紹介．骨盤 CTにて閉鎖孔へルニアによ る腸閉塞と診断, 緊急手術となった。

入院時現症：身長 $163 \mathrm{~cm}$, 体重 $45 \mathrm{~kg}$ ，血圧 $112 / 70$ $\mathrm{mmHg}$, 脈拍70回/分, 腹部膨隆, 腹部全体に圧痛認め た.

入院時検査所見 : IVBC 6.701 $\mathrm{ul}$, CRP $5.2 \mathrm{mg} / \mathrm{dl}$ と炎症反応の上昇, BUN $22.2 \mathrm{mg} / \mathrm{dl}, \mathrm{Cr} 0.7 \mathrm{mg} / \mathrm{dl}$ と 脱水所見を認めた（表 1 ）。

2004 年 8 月24日受付 2004年12月15日採用

〈所属施設住所〉

テ $49 x-85011$ 要知県海部郡弥富町前ヶ須新田南本田396
腹部単純 CT：左嵌頓閉鎖孔へルニア嵌頓を認めた (図 1 )。

手術所見：開腹すると回腸末端より約 $1 \mathrm{~m}$ 口側の 小腸が左の閉鎖孔に Richter 型に嵌頓していた。嵌頓 腸管を用手的に還納したところ血流は保たれており， 閉鎖孔を縫縮し手術を終了した。

術後経過：術後肺炎併発したが回復し, 術後40日目 退院となった。

患者 $2: 82$ 藏, 男性.

主訴: 右大腿部痛, 腹痛.

家族歴，既往歴：特記すべきことなし。

現病歴：2000年 7 月 20 日より右大腿部痛出現. 7 月 23日腹痛, 嘔吐が出現し, 当院救急外来受診. 骨盤 CT にて閉鎖孔へルニアによる腸閉塞と診断, 即日緊急手 術となった。

入院時現症：身長 $150 \mathrm{~cm}$ ，体重 $35 \mathrm{~kg}$ ，血压 $98 / 50$ $\mathrm{mmHg}$, 脈拍70回 $/$ 分, 体温 $37.5^{\circ} \mathrm{C}$, 腹部膨隆, 腹部全 体に圧痛を認めた。

入院時検查所見：WBC $13,700 / \mathrm{ul}$, CRP $6.7 \mathrm{mg} / \mathrm{dl}$ と炎症反応の上昇, BUN $29.9 \mathrm{mg} / \mathrm{dl}, \mathrm{Cr} 1.0 \mathrm{mg} / \mathrm{dl}$, TP $8.8 \mathrm{~g} / \mathrm{dl}$ と脱水所見が認められた（表 2 ).

腹部単純 $\mathrm{X}$ 線写真：小腸拡張とニボー像を認めた。

腹部 CT 所見：回腸レヘルまで著明な腸管拡張, 右 閉鎖孔に嵌頓した腸管と，左閉鎖孔にヘルニア变と思 われる軟部組織影を認め, 右嵌頓閉鎖孔へルニア, 左 非嵌頓閉鎖孔へルニアと診断した（図 2 ).

手術所見：開腹すると回腸末端より約 $1 \mathrm{~m}$ 口側の 
表 1 症例 $1 ： 入$ 院時血液検查所見

\begin{tabular}{|c|c|c|c|}
\hline \multirow{2}{*}{$\begin{array}{c}\text { 血液検查 } \\
\text { WBC }\end{array}$} & \multicolumn{3}{|c|}{ 生化学娭査 } \\
\hline & $6,700 / \mathrm{ul}$ & $\mathrm{TP}$ & $5.8 \mathrm{~g} / \mathrm{dl}$ \\
\hline RBC & $4.33 \times 10^{6} / \mathrm{ul}$ & T-bil & $2.2 \mathrm{mg} / \mathrm{dl}$ \\
\hline $\mathrm{Hgb}$ & $12.3 \mathrm{~g} / \mathrm{dl}$ & GOT & $15 \mathrm{IU} / 1$ \\
\hline \multirow[t]{2}{*}{ Plt } & $20.1 \times 10^{4} / \mathrm{ul}$ & GPT & $51 \mathrm{IU} / 1$ \\
\hline & & $\mathrm{CPK}$ & $46 \mathrm{IU} / 1$ \\
\hline \multicolumn{2}{|c|}{ 血菠ガス分析 } & Amy & $388 \mathrm{IU} / 1$ \\
\hline $\mathrm{pH}$ & 7.425 & $\mathrm{Na}$ & $137 \mathrm{mmEq} / 1$ \\
\hline $\mathrm{pCO}_{2}$ & $38.3 \mathrm{mmHg}$ & $\mathrm{K}$ & $4.2 \mathrm{mEq} / 1$ \\
\hline $\mathrm{pO}_{2}$ & $88.7 \mathrm{mmHg}$ & $\mathrm{Cl}$ & $101 \mathrm{mEq} / 1$ \\
\hline $\mathrm{HCO}_{3}-$ & $24.7 \mathrm{mmol} / 1$ & BUN & $22.2 \mathrm{mg} / \mathrm{dl}$ \\
\hline $\mathrm{BE}$ & $0.9 \mathrm{mmol} / 1$ & $\mathrm{Cr}$ & $0.7 \mathrm{mg} / \mathrm{dl}$ \\
\hline \multirow[t]{2}{*}{$\mathrm{O}_{2}$ sat } & $96.2 \%$ & PG & $133 \mathrm{mg} / \mathrm{dl}$ \\
\hline & & CRP & $5.2 \mathrm{mg} / \mathrm{dl}$ \\
\hline
\end{tabular}

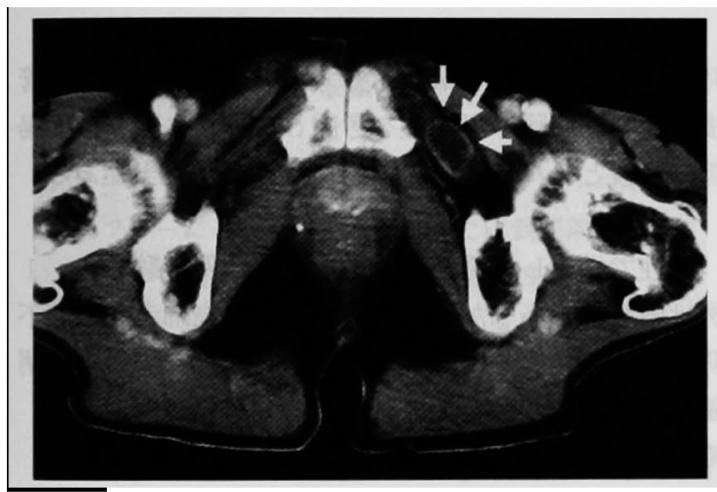

図 1 症例 1 CT 検査：左嵌頓閉鎖孔ヘルニア嵌頓 (矢印)を認めた。

小腸が右の閉鎖孔に Richter 型に嵌頓しており，還納 した腸管は不可逆的に循環障害に陌っていたため小腸 切除術を施行し, 閉鎖孔は縫縮した. 左の閉鎖孔はへ ルニア垂を結禁切除し，縫縮した。

術後経過：術後肺炎を併発し，長期入院を要したが， 術後60日目に軽快退院した。

\section{考 察}

閉鎖孔へルニアは閉鎖管の入口部をヘルニア門とす るヘルニアであり，本邦で約800例ほどの報告例であ $3^{1) \sim 4}$. 高齢女性に圧倒的に多〈5>ー7, 男性発症例は学 会報告も含め 40 例ほどである．男女あわせた術前診断 率は，これまで1991年までの症例集計では37\%であっ たのに対し，1992年から1994年の症例では75\%と向上 し，1995年から2000年までの症例では83\%と著しく向 上している4.これはCT の普及による影響と考えら れる.
表 2 症例 2 : 入院時血液検査所見

\begin{tabular}{clll}
\hline 血液検査 & & \multicolumn{3}{c}{ 生化学検査 } \\
$\mathrm{WBC}$ & $13.700 / \mathrm{ul}$ & $\mathrm{TP}$ & $8.8 \mathrm{~g} / \mathrm{dl}$ \\
$\mathrm{RBC}$ & $4.70 \times 10^{6} / \mathrm{ul}$ & $\mathrm{T}$-bil & $0.8 \mathrm{mg} / \mathrm{dl}$ \\
$\mathrm{Hgb}$ & $13.5 \mathrm{~g} / \mathrm{dl}$ & $\mathrm{GOT}$ & $40 \mathrm{IU} / 1$ \\
$\mathrm{Plt}$ & $29.2 \times 10^{4} / \mathrm{ul}$ & $\mathrm{GPT}$ & $12 \mathrm{IU} / \mathrm{l}$ \\
& & $\mathrm{CPK}$ & $97 \mathrm{IU} / 1$ \\
血液ガス分析 & $\mathrm{Amy}$ & $45 \mathrm{IU} / \mathrm{l}$ \\
$\mathrm{pH}$ & 7.399 & $\mathrm{Na}$ & $137 \mathrm{mmEq} / 1$ \\
$\mathrm{pCO}_{2}$ & $24.8 \mathrm{mmHg}$ & $\mathrm{K}$ & $6.6 \mathrm{mEq} / 1$ \\
$\mathrm{pO}_{2}$ & $\times 2.1 \mathrm{mmHg}$ & $\mathrm{Cl}$ & $99 \mathrm{mEq} / 1$ \\
$\mathrm{HCO}_{3}{ }^{-}$ & $15.0 \mathrm{mmol} / 1$ & $\mathrm{BUN}$ & $29.9 \mathrm{mg} / \mathrm{dl}$ \\
$\mathrm{BE}$ & $-7.8 \mathrm{mmol} / 1$ & $\mathrm{Cr}$ & $1.0 \mathrm{mg} / \mathrm{dl}$ \\
$\mathrm{O}_{2} \mathrm{sat}$ & $94.6 \%$ & $\mathrm{PG}$ & $135 \mathrm{mg} / \mathrm{dl}$ \\
& & $\mathrm{CRP}$ & $6.7 \mathrm{mg} / \mathrm{dl}$ \\
\hline
\end{tabular}

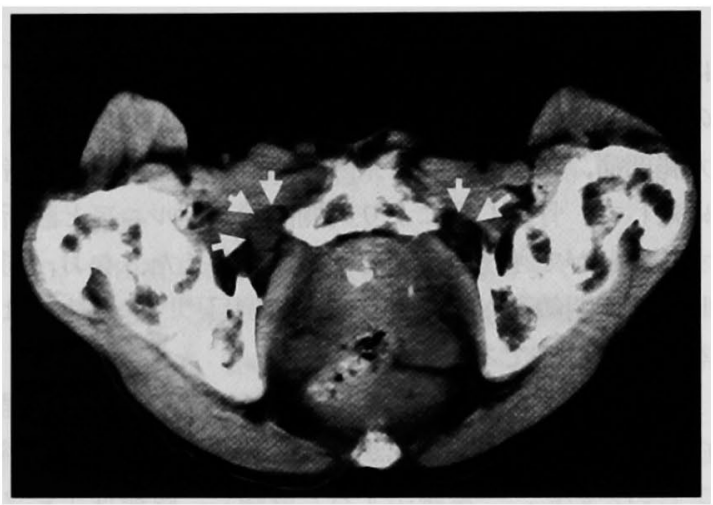

図 2 症例 2 CT 検査：右嵌頓閉鎖孔へル二ア (矢印), 左非嵌頓閉鎖孔へルニア（矢印）を認めた。

ここ10年間の男性閉鎖孔へルニアの本邦報告例は， 医学中央雑誌から狩猟しえた限りでは10例防 17で自 験例 2 例を含めて 12 例である(表 3 )。 女性と同様，る いそうの目立つ高龄者に発症しているが，男性発症例 の特徵としては, 次の 2 点が挙げられる. (1)入院から 24時間以内の診断率においては33\%にすぎない. (2)腹 部症状で発症してからの病状の進行が女性に比して早 く，自然解除されずに全例手術に移行している.

まず，男性において早期の診断率が低い理由として は, 男性のため閉鎖孔へルニアを念頭に置いていない ことにより，骨盤 CT の撮影が施行されていないこと が一因と考えられる，今回報告の症例 Iでは，イレウ ス管を留置する前に骨盤 CT を施行せず，原因不明の 腸閉塞として，3 日間経過観察された。この診断の遅 れが, 術後長期入院の一因になったと考えられた.そ こで, それ以後当院では高齢者の腸閉塞症例では男女 
表 3 最近10年間の男性閉鎖孔ヘルニア報告例

\begin{tabular}{|c|c|c|c|c|c|c|c|}
\hline 報告者 & 年此命 & 症状 & & 彭断方法 & 入院から手術まて & 術前診断, イレウス管留置の有無 & 術式, 所見 \\
\hline 中鳰(1995) & 56 & 他のヘルニアが主䂨 & $\mathrm{CT}$ & ヘルニオグラフィー & 一 侍機手術 & 閉銷孔へルニアと他のヘルニア & 鼠径法 \\
\hline 中囬(1995) & 74 & 他のヘルニアが主訴 & $\mathrm{CT}$ & ヘルニオグラフィー & 一 待機手術 & 閉銷孔ヘルニアと他のヘルニア & 䖢徍法 \\
\hline 中呞(1995) & 78 & 他のヘルニアが主訴 & $\mathrm{CT}$ & ヘルニオダラフィー & 一 待機手術 & 閉鎮孔ヘルニアと他のヘルニア & 鼠径法 \\
\hline 岩崎(1996) & 79 & イレウス & & CT, US & 2日 & 左能頓閉銷孔ヘルニア & 開腹 \\
\hline 原田(1996) & 91 & イレウス & $\mathrm{CT}$, & ，イレウス管造影 & 2日 & 右嵌頓閉鎖孔へルニア(イレウス管留置) & 開腹 \\
\hline 日高(1996) & 86 & イレゥス & & CT & 不明 & 両側嵌頓閉銷孔へルニア(イレウス管留置) & 開腹 \\
\hline 䋲花(1997) & 75 & イレウス & & $\mathrm{CT}$ & 10日 & 右嵌頓閉銷孔ヘルニア (イレウス管留置) & 開腹(穿孔) \\
\hline 市村(1998) & 77 & イレウフ, HRS & & $\mathrm{CT}$ & 2日 & 右嵌頓閉鎖孔へルニア & 開腹 \\
\hline 内田(2000) & 86 & イレウス & & $\mathrm{CT}$ & 16日 & 左嵌頓閉銷孔ヘルニア (イレウス管留置) & 開腹 \\
\hline 中山(2002) & 73 & イレウス & & CT & 3日 & 原因不明イレウス & 開腹 \\
\hline 自験例(2004) & 79 & イレウス & & $\mathrm{CT}$ & 3日 & 左炭頓閉鎖孔ヘルニア(イレゥス管留置) & 開腹 \\
\hline 自駩例(2004) & 82 & イレウス, HRS & & CT & 1日 & 万嵌頓閉銷孔ヘルニア, 左非嵌頓閉鎖孔へルニア & 開腹(腸切あり) \\
\hline
\end{tabular}

HRS;Howship-Romberg sign

にかかわらず，骨盤 CT 検査を施行し閉鎖孔ヘルニア の有無を検索するようにした，その結果，症例 2 では， 大腿部痛, 腹痛を主訴に来院された腸閸塞の男性患者 に対して，骨盤 CTにより両側閉鎖孔へルニアと診断 することができ，即日緊急手術をなしえた。なお，同 時性両側閉鎖孔へルニアは本邦17例目 ${ }^{18119}$, 男性では 本邦 3 例目 ${ }^{8 / 9)}$ であった。

次に，男性発症例が女性に比して病状進行が早い理 由としては男性の閉鎖孔が女性よりも狭く，可動性が 乏しいために，一度脱出すると嵌頓し，絞扼性イレウ スに宿りやすいことが考えられる，女性の場合，経過 観察の段階でヘルニア倣頓が自然解除されたり，自然 解除と嵌頓を繰り返し長い経過時間をたどる症例201211 も存在する。しかし，男性の場合は，腹部症状が出現 するとイレウス管留置による減圧が効を奏しても自然 解除されたという報告はなく，全例手術に移行してい た. 症例 1 では入院当日からのイレウス管による減圧 が効を奏し腸切除を免れたが，へルニア門は狭く腸管 が嵌頓しており，術中還納に難涉した。症例 2 では入 院当日に手術施行したものの，腸管は狭いヘルニア門 に絞扼されており，腹腔内に戻すのにヘルニア門の切 開を必要とした，嵌頓腸管は既に循環障害に宿ってい たため腸切除を必要とした。

以上の検討から，男性閉鎖孔へルニアは自然解除は 望めず, 腹部症状出現から手術までに時間が経過する と腸管が循罢障害に宿る可能性が高くなるので，女性 よりも更なる早期診断が重要である，治療法としては 診断後，速やかに手術を行うことが原則である。その ほとんどにおいて，腸管嵌頓のためイレウス症状が短
時間に出現しており緊急を要するので, 整復時の腸管 損傷，腸管切除の可能性を考慮して開腹により嵌頓腸 管の整復とへルニア孔の閉鎖を行うのが妥当である.

\section{結語}

男性で発症した閉鎖孔ヘルニアを 2 例経験した。1 例は両側性であった。男性においても高齢者の原因不 明の腸閉塞症例では早期に骨盤 CT 検查を施行し，閉 鎖孔ヘルニア嵌頓腸管の有無を検索する必要がある. そして速やかに開腹手術を施行すべきである。

\section{文献}

1）渡橋和政，佐々木童，井上邦典地：閉銷孔へル二 アの 2 症例一本邦報告181例の文献的考察. 日臨外 医会誌 $45 ： 967-973,1984$

2）森村尚登, 西山潔, 渡会伸治他：手術前に診断 できた閉鎖孔へルニアの 1 例並びに本邦報告246 例の文献的考察. 日臨外医会誌 $49: 132-138$, 1988

3）鈴木修司, 宮内倉之助, 藤本 章他：診断に苦慮 し緊急手術に至った閉鎖孔へルニアの1例一本邦 報告314例の検討一。日腹部救急医会誌 $15: 983$ $-986,1995$

4）河野哲夫, 日向 理, 本田勇二：閉銷孔へルニア 一最近 6 年間の本邦報告257例の集計検討一. 日臨 外会誌 $63: 1847-1852,2002$

5）高桑一喜, 小田幸夫, 渡辺直純地：閉鎖孔へルニ アの 2 例. 日臨外医会誌 $58 ： 466-470,1997$

6）原一生, 宮崎礼寿, 高山雄二他：閉鎖孔へル二 ア12症例の檢討. 袘と研 $76: 2442-2446,1999$

7) 南 光昭, 殿田重彦, 湯川裕史他：進行胃癌によ 
るるい瘦が誘因と考えられた異時性耐側閉鎖孔へ

ルニア. 日臨外会誌 $61: 518-522,2000$

8) 山田和彦、生駒 茂, 渡辺和礼他：術前診断し之 た閉鎖孔へルニアの1 例一特に超音波検查の有用 性について一。臨外 $44: 1252-1255,1989$

9）日高康雄, 円岡 寿, 伊藤喜三男他：腹部 CT が 診断に有効であった閉鎖孔へルニアの3 例. 埼玉 医会誌 $31 ： 144-147,1996$

10) Nakayama $T$, Kobayashi $S$, Shiraishi $K$, et al : Diagnosis and Treatment of obturator hernia. Keio J Med $51: 129-132,2002$

11）滝花義男, 別府正典, 野村照之他：血液透析患者 に発生した閉鎖孔へルニアの1例.臨透析 13 ： $1545-1548,1997$

12）原田直樹，今西 築，小西宗春他：術前診断しえ た閉鎖孔へルニア嵌頓の1 例.甲南病医誌 16 ： $29-31,1996$

13）中鳮 昭, 菅野箸英，長浜雄志他：ヘルニオグラ フィーによって術前診断しえた両側閉鎖孔へルニ アの3 例. 臨外 $45: 393-396,1990$

14）中嶋 昭, 佐藤 康, 新井健広他: 閉鎖孔へル二 アの鼠径法による修復術。手術 49：1829-1832，
1995

15）内田一徳，小川吕輝，巻幡栄一他：術前 CTにて 診断し得た閉鎖孔へルニアの2 例. 広島医 53 ： $534-536,2000$

16）市村龍之助, 高橋 透, 水戸康文他：術前診断し 得た男性閉鎖孔へルニアの1例。北海道外科誌 $43: 203-205,1998$

17）岩崎 誠，酒井秀精：閉鎖孔ヘルニアの 4 例. 日 臨外医会誌 $57: 2546-2549,1996$

18）長尾和宏，姫野誠一，桐山和雄他：両側同時性閉 鎖孔へルニアの 1 例.日消病会誌 $92: 980-983$, 1995

19）山田 誠, 斉藤史朗, 安藤公隆他：超高路者に発 症した同時性両側閉鎖孔へルニアの 1 例。日臨外 会誌 65：1701- 1705，2004

20）江田 泉, 矢野匡亮, 田中規幹他：自然還納を確 認し鼠径法にて待機的に修復術を施行した閉鎖孔 ヘルニアの 1 例. 日臨外会誌 $61: 1340-1343$, 2000

21）岡田禎人： 4 年間，嵌頓と自然整復をくり返した 閉鎖孔へルニアの 1 例. 日腹部救急医会誌 24 ： $673-676,2004$

\title{
TWO CASES OF OBTURATOR HERNIA IN MEN
}

\author{
Takumi SAKAKIBARA, Akio HARADA and Toyohisa YAGUCHI \\ Department of Surgery, Aichi Koseiren Kainan Hospital
}

Obturator hernia is extremely uncommon in men. This paper deals with two male cases of obturator hernia.

Patient 1, a 79-year-old man, seen at the hospital because of abdominal pain and vomiting was indwelt a long tube with a diagnosis of intestinal obstruction of unknown origin. No symptomatic remission of ileus was attained, and he was operated on after the diagnosis of intestinal obstruction due to obturator hernia was made by abdominal CT scans 4 days after admission.

Patient 2, an 82-year-old man, seen at the hospital because of a several-day history of femoral pain and vomiting was diagnosed as having intestinal obstruction due to obturator hernia by abdominal CT scans. An emergency operation was carried out on the same day.

In a review of male cases of obturator hernia including ours, no cases in which their hernias were spontaneously relieved have been reported, and, from that standpoint, early diagnosis by means of pelvic CT scanning and operation are especially important for male cases. These two cases are presented here, together with some discussion on clinicopathological characteristics of male obturator hernia. 